\title{
NONSPECIFIC CELLULAR AND HUMORAL DEFENCE MECHANISMS IN SHEATFISH (Silurus glanis)
}

\author{
M. MORAND ${ }^{1}$, A. K. SIWICKI ${ }^{2}$, F. POZET ${ }^{1}$, J. C. VINAIZE ${ }^{3}$, N. KECK ${ }^{1}$ \\ ${ }^{1}$ Laboratoire Départemental d'Analyses Conseil Général du Jura, Lons le Saunier, France \\ ${ }^{2}$ Department of Epizootiology with Clinic of Infection Diseases Faculty of Veterinary Medicine, \\ University in Olsztyn, Poland \\ ${ }^{3}$ Direction des Services Vétérinaires, Bourg en Bresse, France
}

Received July 22, 1998

Accepted September 21, 1998

\begin{abstract}
Morand, M., A. K. Siwicki, F. Pozet, J. C. Vinaize, N. Keck: Nonspecific Cellular and Humoral Defence Mechanism in Sheatfish (Silurus glanis). Acta vet. Brno 1998, 67: 335-338.

Early diagnosis of fish diseases by control of immunological parameters is one of the most important part of prophylactic in intensive fish culture. For the first time, the nonspecific cellular and humoral defence mechanisms were studied in farming sheatfish, using two size of fishes weighing $300-500 \mathrm{~g}$ and $2000-3000 \mathrm{~g}$. For each group, the respiratory burst activity and the potential killing activity of blood and pronephric phagocytes, the proliferative ability of lymphocytes and the myeloperoxidase activity in PMN cells was measured. The lysozyme and ceruloplasmine activity as well as total proteins and immunoglobulins in serum are also presented. Those results will be used for control the defence mechanisms and protection against infection diseases of sheatfish raised in farming conditions.
\end{abstract}

Sheatfish, aquaculture, nonspecific cellular and humoral immunity

Successful commercial production of most cultured fish species has been facilitated by the intensification of larval and fingerling rearing techniques. Siluriformes species are no exception and early attempts at larval rearing in ponds were soon superseded by intensive hatchery production. Traditional aquaculture of Siluriformes in Europe and Asia is more directed towards whole fish products but some traditional processing has been developed, as is found in Africa, to allow for storage of the fish. Recent developments in silurid aquaculture, sheatfish (Silurus glanis) in Europe and catfish (Ictalurus punctatus) in USA, have been associated with the future processing of fish (Biology and Aquaculture of Siluriformes, Montpellier 1994).

There is, however, little information on the ability of Siluriformes to respond to such processing compared to rainbow trout or to carp, species which are often used as a model for experimental studies. A great deal of information about channel catfish physiology, defence mechanisms and diseases has been published, but concerning other Siluriformes species, we have only little information, especially concerning sheatfish (Silurus glanis). Among all of the viruses known to be pathogenic for fish, only a few are related to diseases of cultured sheatfish. These include: the sheatfish herpes virus (Bekesi et al. 1981), and the sheatfish iridovirus (A $h n$ e et al. 1989, A hne et al. 1997), an irido-like agent associated with systemic infections was isolated in France (Pozet et al. 1992).

Moreover, the only fish species-specific bacterial pathogen entailing high mortality in the sheatfish culture is Edwardsiella tarda, which has been isolated in LDA 39 (Laboratoire 
Départemental d'Analyse du Jura) from sheatfish suffering a septicaemia with haemorrhagic barbells and fins (Morand, unpublished results). Other pathogenic bacteria are opportunistic bacteria: Aeromonas hydrophila and Pseudomonas sp. Fungal infections and ichtyophtiriosis sometimes seem to have a significant economic impact for the sheatfish farming in France.

Fish pathologist should keep records for year-to-year comparisons of as many health parameters of their stock as time permits. Data should include information from morphological observations, routine samples for the presence of common pathogens and records on blood samples for analyse the physiological condition and nonspecific protection against diseases.

In the present study, we examined the nonspecific cellular and humoral defence mechanisms of sheatfish (Silurus glanis) grown under farming conditions.

\section{Materials and Methods}

In order to determine the nonspecific cellular and humoral defence parameters, 20 healthy sheatfish. weighing 300-500 g and 20 fish weighing $2000-3000 \mathrm{~g}$ were examined. Fish were purchased from a local fish farm (Ain. France) and fed commercial pellets containing $50 \%$ protein (Super Aquasarb, Tours. France). Fish were anaesthetized in Propiscin (IFI, Poland) and blood from the caudal vein (Vacutainer systems, Becton Dickinson, England) as well as the pronephros for cells separation were removed.

A modification by Siwicki et al. (1996) of a technique presented by Secombes (1990) was used to study the respiratory burst activity of the blood and pronephric phagocytes stimulated by Phorbol myristate acetate (PMA, Sigma). The plates were read with a micro reader, $O D=620 \mathrm{~nm}$ (Labsystems iEMS Reader MF. Finland).

A modification by Siwicki and Anderson (1993) of a technique presented by Rook et al (1985) was used to measure the potential killing activity of the blood and pronephric phagocytes. The same protocol as in the respiratory burst assay was used to obtain adherent cells. The phagocytes were stimulated with 1001 of $0.2 \%$ NBT solution in PBS containing living Aeromonas hydrophila $\left(1 \times 10^{8} / \mathrm{ml}\right)$ was added and incubated $30 \mathrm{~min}$ at $30^{\circ} \mathrm{C}$.

The proliferative ability of the lymphocytes was determined by the MTT colorimetric assay method according to Mosmann (1983) with modification for fish species by Siwicki et al (1996). The mitogens concanavaline A (ConA, Sigma) at concentration $64 \mathrm{~g} / \mathrm{ml}$ or lipopolysaccharide (LPS, Sigma) at concentration $160 \mathrm{~g} / \mathrm{ml}$ were used for stimulation of lymphocytes.

The myeloperoxidase activity in PMN cells was determined by a cytochemistry method (Siwicki and Anderson 1994).

The lysozyme level in the serum was measured in a turbidimetric assay (Siwicki and Anderson 1993).The standard used was hen egg white lysozyme (Sigma) and Micrococcus lysodeikticus suspension in buffer.

The ceruloplasmine activity in the serum was determined according to Siwicki and Studnicka (1986) with modifications for microcellular methods. Serum was incubated in microplates for $15 \mathrm{~min}$ in acetate buffer (pH 5.2) containing $0.2 \%$ p-phenylenediamine (PPD). Some sodium azide $(0.02 \%)$ was used to stop the reaction. Activity was measured at $540 \mathrm{~nm}$ on the micro-reader.

Total proteins in the serum were measured by colorimetric Lowry micro methods (Sigma Diagnostic Kits 690A).

Total immunoglobulins were also measured, using the Lowry micro methods, with modifications by Siwicki and Anderson (1993). This technique consists at first in precipitating the immunoglobulin out of the serum with polyethylene glycol $(10000 \mathrm{kDa})$.

For statistical analysis, means and standard deviations for all test values were performed using the Student $t$ test.

\section{Results and Discussion}

In this examination, we analysed for the first time the level of nonspecific cellular and humoral defence mechanisms in healthy sheatfish from farm. This basic study gives very important information about physiological levels of nonspecific protection against pathogens in intensive sheatfish culture.

In our study, we did not observe statistically different levels between the two groups of fish: $200-300 \mathrm{~g}$ and $2000-3000 \mathrm{~g}$ concerning the nonspecific cellular and humoral defence mechanisms (data not presented). The activity of phagocytes measured by respiratory burst 
activity and potential killing activity of blood phagocytes and pronephric macrophages are presented in Table I. The results showed that a higher respiratory burst activity and potential killing activity were observed in pronephric macrophages, compared to blood phagocytes.

The activity of pronephric lymphocytes analysed by proliferative response on the mitogens ConA and LPS are presented in Table 1. The analyses of the results showed, that higher proliferative response on the ConA mitogen was observed.

Table 1

The nonspecific cellular and humoral defence mechanisms in healthy sheatfish from farm (mean SD; $n=40$ )

\begin{tabular}{|l|c|}
\hline Immunological parameters & Mean $\pm \mathrm{SD}$ \\
\hline Cell-mediated immunity & \\
Respiratory burst activity of blood phagocytes (OD 620 nm) & $0.27 \pm 0.04$ \\
Respiratory burst activity of pronephric macrophages ( OD 620 nm) & $0.41 \pm 0.05$ \\
Potential killing activity of blood phagocytes (OD 620 nm) & $0.28 \pm 0.04$ \\
Potential killing activity of pronephric macrophages OD 620 nm) & $0.37 \pm 0.05$ \\
Lymphocyte proliferation stimulated by ConA (OD 620 nm) & $0.39 \pm 0.05$ \\
Lymphocyte proliferation stimulated by LPS (OD 620 nm) & $0.28 \pm 0.04$ \\
& \\
Nonspecific humoral defence mechanisms & $6.75 \pm 0.9$ \\
Lysozyme activity in serum (mg/l) & $32.5 \pm 2.8$ \\
Ceruloplasmin activity in serum (IU) & $36.8 \pm 3.0$ \\
Total protein level in serum (g/l) & $6.5 \pm 1.0$ \\
Total Ig level in serum (g/l) & \\
\hline
\end{tabular}

The nonspecific humoral defence mechanisms parameters: lysozyme and ceruloplasmine activity and total protein with immunoglobulin (Ig) level in serum are presented in Table 1.

In our in vitro experimental study, we examined the influence of natural immunomodulator lysozyme dimer (KLP-602) from Nika Health Products (USA) on the immunocompetent cells activity in sheatfish fingerling (mean weight $65 \mathrm{~g}$ ). The results presented that lysozyme dimer (KLP-602) activated the phagocytic ability of pronephric macrophages and proliferative responses of pronephric lymphocytes stimulated by ConA and LPS (Morand et al. 1998). In this experimental study, the lower activity of pronephric macrophages and lymphocytes in control group were observed compared to our present examination. The analyses of these results suggested that probably in younger fish ( less that $100 \mathrm{~g}$ of body weight) the lower activity of cell-mediated immunity will be observed.

The basic information about cellular and humoral defence mechanisms in healthy sheatfish coming from intensive culture are very important for early diagnosis of infection diseases. Actually it is very difficult to compare these results, because we have very few information about phagocytic ability of blood and pronephric phagocytes and lymphocyte activity in sheatfish. This study gives us preliminary informations about nonspecific defence mechanisms in farmed sheatfish. Based on these informations, it is easy to control the health condition and it will be possible to apply for early diagnosis of infectious diseases as well as to control the effects of environmental contamination. 


\section{Nespecifické buněčné a humorální obranné mechanismy u sumce velkého (Silurus glanis)}

Včasná diagnostika chorob ryb pomocí kontroly imunologických parametrů je jedním z nejdůležitějších preventivních opatření při intenzivním chovu ryb. Nespecifické buněčné a humorální obranné mechanismy byly studovány u sumce velkého. Použity byly dvě skupiny ryb, jedna o hmotnosti 300-500 g a druhá o hmotnosti 2000-3000 g. $\mathrm{V}$ každé skupině byla měřena aktivita respiračního vzplanutí a potenciální zabíječské aktivity krevních a pronefrických fagocytů, schopnost proliferace lymfocytů a myeloperoxidázová aktivita polymorfonukleárních (PMN) buněk. Prezentována je aktivita i lysozymu a ceruloplasminu $v$ séru. Tyto výsledky byly použity při kontrole obranných mechanismů a ochraně před infekčními chorobami u sumců velkých chovaných na farmách.

\section{References}

AHNE, W.. SCHLOTFELDT. H. J., THOMSON, I. 1989: Fish viruses: Isolation of an icosahedral cytoplasmic deoxyribovirus from sheatfish (Silurus glanis). J. Vet. Med. $36: 333-336$

AHNE, W., BREMONT, M., HEDRICK, R. P., HYATT, A. D., WHITTINGTON, R.J. 1997: Special topic review: Iridoviruses associated with epizootic haematopoietic necrosis (EHN) in aquaculture. World J. Micr. Biotech. 13: $367-373$

BEKESI, L.. KOVACS-GEYER, E., RATZ, F., TURKOVICS, O. 1981: Skin infection of the sheatfish (Silurus glanis) caused by the herpes virus. In Proc. Int. Sem. On Fish, Pathogens and Environment in European Polyculture. Fisheries Research Institute, Szarvas, Hungary: 58-69.

MORAND, M.. SIWICKI, A. K., POZET, F., VINAIZE, J. C., KECK, N. 1998: Effects of dimerized lysosyme (KLP-602) on the cellular and humoral defence mechanisms in sheatfish (Silurus glanis): in vitro and in vivo study. Vet. Research - in press

MOSMANN. T. 1983: Rapid colorimetric assay for cellular growth and survival: Application to proliferation and cytotoxicity assays. J. Immunol. Meth. 65: 55-63

POZET, F., MORAND, M., MOUSSA, A., TORHY, C., DE KINKELIN, P. 1992: Isolation and preliminary characterization of a pathogenic icosahedral deoxyribovirus from the catfish Ictalurus melas. Dis. Aquat. Org. $14: 35-42$

ROOK, G. A. M., STEELE, J., UMAR, S., DOCKRELL, H. M. 1985: A simple method for the solubilization of reduced NBT, and its use as a colorimetric assay for activation of human macrophages by gamma-interferon. J. Immunol. Meth. 82: 161-167

SECOMBES. C. J. 1990: Isolation of salmonid macrophages and analysis of their killing activity. Techn. Fish Immunol. 1: 137-154

SIWICKI, A. K., STUDNICKA, M. 1986: Ceruloplasmin activity in carp (Cyprinus carpio). Bamidgeh 38: 126129

SIWICKI, A.K., ANDERSON, D. P. 1993: Nonspecific defence mechanisms assay in fish. II. Potential killing activity of neutrophils and macrophages, lysozyme activity in serum and organs and total immunoglobulin (TIg) levels in serum. Fish Diseases Diagnosis and Prevention's Methods. FAO-Project GCP/INT/526/JPN, IFI Olsztyn: 105-112

SIWICKI, A. K., ANDERSON, D. P. 1994: Dietary intake of immunostimulants by rainbow trout affects nonspecific immunity and protection against furunculosis. Vet. Immunol. Immunopathol. 41: 124-139

SIWICKI, A. K., MIYAZAKI, T., KOMATSU I., MATSUSATO, T. 1996: In vitro influence of heat extract from firefly squid Watasenia scintillans on the phagocyte and lymphocyte activities in rainbow trout Oncorhynchus mykiss. Fish Pathology 31: 1-7 